\title{
Leadership Attitude through The Acts of Planning in The Management and Development of Inclusive School
}

\author{
E. Purbaningrum \\ Universitas Negeri Surabaya \\ Surabaya, Indonesia
}

\begin{abstract}
This research was aimed at revealing the leadership attitude through the acts of planning which grown by each school member in an inclusive school. This research used a qualitative approach within a case study design. The data collection techniques used in this research were interviews and observations. The research result showed that the act of planning which was implemented through various kinds of school programs or activities in order to give some treatments to the disabled children was the most crucial pattern of building the leadership attitudes done by each individual or school member at 'Creative' Muhammadiyah 16 of Elementary School Surabaya. Moreover, the leadership attitudes through acts of planning showed by each individual or school member also had affected the success in the increase of the school quality which give a good or positive impact on the community trust to the existence and development of this inclusive school.
\end{abstract} School

Keywords- Leadership Attitude, Management, Inclusive

\section{INTRODUCTION}

Nowadays leadership becomes important as an effort done by someone to influence and support other people in order to get their high enthusiasms in working or doing something useful to achieve the expected goals or targets [8, 10, 4, 15]. It also has significant roles in supporting each individual to do their jobs and keep relationship with others in the establishment, management, and development of the inclusive schools. However, there has not been enough evidences about the patterns of the leadership attitudes which must be owned or grown by each individual or school member in the inclusive school. As known that inclusive school is the educational system which do not differentiate between the students with and without disabilities to learn together in the same room [14, 7]. Furthermore, the success of establishment, management, and development of the inclusive schools cannot be separated from some patterns of the leadership attitudes through the acts of planning owned or grown by each individual or school member who must be responsible for the improvement of the quality of the inclusive system held.

Huber (2004) found that the leadership attitudes had great contributions to the school development and quality [12]. Therefore, it is suggested that schools have certain programs which lead to prepare each individual or school member in growing the leadership attitudes in their lives. Furthermore, Bush (2006) showed that the leadership attitudes showed by each individual or school member would emerge some certain patterns of craved good behaviors for other people including students in the school [3]. Meanwhile, Berry (1997) found that the leadership attitudes owned and grown by each school member contributed to the school development and management [2].

Based on the information above, this research was aimed at qualitatively revealing the leadership attitudes through some acts of planning in the management and development of the inlcusive schools. Therefore, the writer tried to propose some research questions as follows:

a. How are the leadership attitudes through the acts of planning grown by each individual or school member of 'Creative' Muhammadiyah 16 Elementary School Surabaya in managing and developing the inclusive educational system?

b. What are the impacts of the patterns of the leadership attitudes through the acts of planning grown by each individual or school member of 'Creative' Muhammadiyah 16 Elementary School Surabaya in managing and developing the inclusive educational system?

\section{METHOD}

This research used a qualitative approach in order to naturally explore and interpret all events and realities in relation to the patterns of the leadership attitudes through the acts of planning in managing and developing the inclusive 
education or school. Therefore, this research also used a case study design.

This research was conducted in an inclusive school located in Surabaya. It was known as 'Creative' Muhammadiyah 16 Elementary School. This research also involved some participants as the sources of the data consisting of headmaster, vice of head master, and teachers in the inclusive school investigated. This research applied interview and observation to collect the data with the use of camera, field note, dan interview checklist.

This research also used a content analysis technique to analyze the data. So this research tried to transcribe, code, and narrate all the interview and observation data to get the answer for the research questions.

\section{RESULTS AND DISCUSSION}

\subsection{Patterns of the Leadership Attitudes through the Acts of Planning at 'Creative' Muhammadiyah 16 Elementary School Surabaya}

The leadership attitudes are also closely related to the acts or abilities of planning something (Yukl 2002, Hoy \& Miskel 1987). In this case, each individual is expected to build their abilities to plan something. This act of planning may entail some influences for other people to plan their own activities successfully. Hence, their efforts of giving the influences to others may grow the leadership attitudes in their lives.

Meanwhile, inclusive schools are assumed to be different. It is because of the existence of the disabled children which need special treaments and programs to be planned (Acrey et al. 2005). Accordingly, building the leadership attitudes through the acts of planning must be done for each individual in the inclusive school.

Based on the investigation, it was known that each individual or school member at 'Creative' Muhammadiyah 16 Elementary School Surabaya had grown the ability to plan some school programs in relation to the management and development of the inclusive school to be able to achieve the goals or targets expected. In this case, the headmaster stated,

"In my opinion, the head master's job is to lead the school well. In this case, the pattern of the leadership attitude that can be showed is by planning some school programs in relation to the management and development of the inclusive school"

Based on the data above, it can be explained that the headmaster was also claimed to have the planning ability as the depiction of the leadership attitudes. The acts of planning was important for the headmaster in relation to manage and develop the inclusive school by arranging and designing some learning programs or activities for the disabled children.
In other cases, vices of the headmaster also required to grow the ability of planning. This was due to their roles to support the school management and development. The statement above was also supported by vice of headmaster who was in charge of the curriculum matter as follows.

"The leadership attitude that must be owned by a vice of headmaster is the ability to plan something. In this case, As the vice of headheadmaster who is in charge of the curriculum matter, I must be able to make a plan related to the application and implementation of the curriculum used in this school."

The data above indicated the role of the act of planning in the implementation of the school curriculum. This meant that the implementation of the school curriculum could not work without some good plans made by vice of headmaster. In this case, the vice of the headmaster also required to build his ability to plan the school programs in terms of the application of the curriculum. This was also delivered by a shadow teacher at 'Creative' Muhammadiyah 16 Elementary School Surabaya as follows.

"The existence and function of a shadow teacher like me are very crucial in the inclusive school. This is because our job is to accompany the students with disability to join or follow the learning activities in the class successfully. Therefore, we are often forced to grow our leadership attitudes through some abilities to plan something such as the school programs to help them."

The data above was another proof about the importance of the planning ability in supporting the management and development of the inclusive school. What had been done by the shadow teacher above was that she actually wanted to show her roles in trying to treat the disabled students by planning some learning activities which were beneficial for them. This act was also known to influence other people to do the same thing.

In summary, overall data above explained that the leadership attitudes cannot be separated from the acts of planning which contributes to influence other people in doing or accomplishing their jobs. In addition, this may function to to support the development of the inclusive school established.

Hence, the acts of planning which lead to the efforts of directing other people to do something is supposed to be the implication of the leadership attitudes grown by each individual or school member in trying to manage and develop the inclusive school. This can also be the strategy in leading the educational organization such as school. This is caused by the ability of planning will be able to elicit the foundation of thinking in holding the school programs or activities [9]. 
Furthermore, the implication of the leadership attitudes in the acts of planning unfurled in the way how each individual tried to influence others to be able to increase their capacity in planning something professionally. The acts of planning also directed other people with references of their own positions to be capable of planning some other school programs for helping the disabled children. This actually proved the contribution of the leadership attitudes through the acts of planning to the management and development of the inclusive schools.

Meanwhile, there was also another thing to be considered in relation to the technique used by each individual in doing such acts of planning the school or learning programs. In this case, each individual at this school liked to work in pair or in group in planning something. This was stated by one the shadow teachers as follows.

"The acts of planning was sometimes not an easy thing to be done. It needs a detail understanding and experiences. Therefore, I usually ask or invite other shadow teachers to join with me in planning something. This is actually to prevent or avoid doing the mistakes in planning something. By inviting other people, we will get many inputs in relation to the different experiences owned by them."

The data above was a proof about certain way performed by each individual at this school in doing the act of planning. In this case, this tendency showed by each individual in doing the act of planning was concerned with having cooperation to avoid making the mistakes. Besides, their different experiences led them to work together in order to get some new and different inputs.

\subsection{Impacts on the Leadership Attitudes through Acts of Planning at 'Creative' Muhammadiyah 16 Elementary School Surabaya}

The acts of planning may direct to the efforts of leading other people to do something in relation to what has been planned (Chukwumah 2015). In this case, the leadership attitude through the acts of planning would create the influence and impacts to the management and development of the inclusive schools. In this case, a class teacher stated,

"Every learning activity needs a good lesson plan made or proposed by the individual. We must be able to ensure that one activity held may work well and sucessfully, so the activity can perform a good result to support the management and development of the inclusive school."

The data above showed that the ability of planning was expected to produce successful work to support the management and development of the inclusive school. The management and development of the inlcusive school needed to be handled profesionally by having various kinds of plans. This also affected to the images from other people about the competence in holding the inclusive programs. The statement above was also supported by the headmaster as follows.

"In planning something related to the emergence of some activities, we are used to working together. We feel that everything that is done together will give some good images to the students. Those images emerge when what we plan as the depiction of our cooperation in planning some activities will result some good decisions."

The data above indicated that every activity that was supposed to help or support the management and development of the inclusive school needed some good plans done by individuals involved in the activity held. It was because by having a good plan, all activities could work well.

In addition, the acts of planning could make each individual being professional for completing their works since everything done needed to be planned before. The inclusive schools, on the other hands, could develop well with all programs that were planned professionally

\section{CONCLUSION}

Based on the result and discussions above, the most important thing is that almost all individuals at 'Creative' Muhammadiyah Elementary School 16 Surabaya had grown their abilities of planning as the depiction of the leadership attitude. Those acts or abilities of planning were used to make some school programs to support the management and development of the inclusive education system held. This was done by inviting other people to work together in planning the school programs.

In addition, what had happened at 'Creative' Muhammadiyah 16 Elementary School in relation to the emergence of the leadership attitudes through some acts of planning also presented an indication about the existence of certain patterns of performing an ability to plan something related to the way how to treat the children with disabilities for getting the development of the inclusive school held or established.

Finally, the implementation of the act of planning performed by each individual also tended to cooperate with others. This tendency was caused by their willingness to avoid doing the mistakes and to get different inputs due to their different experiences in doing the acts of planning something.

\section{REFERENCES}

[1] C. Acrey, et al., "Using universal design to unlock the potential for academic achievement of at risk learners", in Teaching Exceptional Children, Vol. 38 No. 2, pp 22-31, 2005

[2] G. Berry, "Leadership and the development of quality culture in schools", in International Journal of Educational Management, Vol. 11 No.2, pp 52-64, 1997 
[3] T. Bush, "The national college for school leadership: a successful English innovation?", in Phi Delta Kappan, Vol. 87 No. 7, pp 508-511, 2006

[4] T. Bush, Theories of Educational Leadership and Management 3rd edition. London: Sage, 2003

[5] F. O. Chukwumah, "Developing quality strategic plan in secondary school for successful school improvement", in Journal of Education and Practice, Vol. 6 No. 21, pp 136-144, 2015.

[6] M.R. Fairholm, "Leadership and Organizational Strategy", in The Innovation Journal: The Public Sector Innovation Journal, Vol. 14 No. 1, pp 2-16, 2009

[7] M. Friend, \& W.D. Bursick, Including Students with Special Needs: A Practical Guide for Classroom Teachers. New Jersey: Pearson Education Inc., 2012.

[8] J. W. Gardner, On Leadership. New York: The Free Press, 1990

[9] K.S. Groves, "Integrating leadership development and succession planning best practices", in Journal of Management Development, Vol. 26 No. 3, pp 239-260, 2006
[10] P. Hersey, et al., Management of Organization Behavior: Utilizing Human Resources. Upple Saddle Rivers, NJ: Prentice Hall, 1996

[11] Hoy \& Mikel, Educational Administration: Theory, Research, and Practice. New York: Random House, 1987

[12] S.G. Huber, "School leadership and leadership development: Adjusting leadership theories and development programs to values and the core purposes of school", in Journal of Educational Administration, Vol. 42 No. 6, pp 669-684, 2004

[13] R.N. Lusier, \& C.F. Achua, Handbook of Leadership: Theory, Research, and Managerial Applications 3rd edition. New York: The Free Press, 2007

[14] J.B.S. Salvia, \& J.E. Ysseldyke, Assessment in Special and Inclusive Education. Canada: Nelson Education Ltd., 2010

[15] G.A. Yukl, Leadership in Organization 5th edition. Upper Saddle River, New Jersey: Prentice-Hall, 2002. 